\title{
PENGARUH PENILAIAN KINERJA DAN MOTIVASI KERJA GURU TERHADAP PRODUKTIVITAS PENDIDIKAN DI SD NEGERI GUGUS VI KECAMATAN SUNGAITARAB

\author{
Guru SD Negeri 03 Kecamatan Sungaitarab
} \\ Lastri Efida
}

\begin{abstract}
This research was aimed at finding the influence of teachers' work assessment toward teachers' productivity; the influence of teachers' work motivation toward teachers' productivity, and the correlation between teachers' work assessment and teachers' work motivation toward teachers' productivity. This research was correlational research with quantitative method. Population in this research were headmaster and teachers in State Primary School Gugus VI Sungaitarab, there were about 48 peoples. Research data were collected by using questionnaire with likert scale model and were analyzed by using correlational analysis technique and regretion analysis technique by utilizing SPSS. 18 application. The analysis of respondent's acceptance level showed that the teachers' work assessment have a correlation toward teachers' productivity as $85,36 \%$ with 0,829 correlation score as first hypothesis. Teachers' work motivation have a correlation toward teachers' productivity as 52,7\% with 0,50 correlation score as second hypothesis. Teachers' works assessment and teachers' work motivation have correlation toward teachers' productivity as $82,23 \%$ respondent's acceptance level with 00,1 correlation score as third hypothesis.
\end{abstract}

Keyword: Teachers'Work Assessment, Teachers'Work Motivation, Teachers' Productivity, State Primary School Gugus VI Sungaitarab.

\section{PENDAHULUAN}

Pendidikan sangat penting dan menduduki posisi sentral dalam perkembangan karena berorientasi pada peningkatan kualitas sumber daya manusia. Pendidikan merupakan suatu proses transformasi nilai-nilai budaya sebagai kegiatan pewarisan budaya dari suatu generasi ke generasi yang lain. Nilai-nilai kebudayaan tersebut mengalami proses transformasi dari generasi terdahulu sampai pada generasi sekarang dan ke depan.

Kepala Sekolah dan guru yang profesional dan berkualitas harus selalu punya kinerja dan motivasi dalam melakukan inovasi pendidikan dan menunjukkan kinerja dan motivasi kerja yang tinggi serta memiliki produktivitas kerja yang tinggi pula untuk meningkatkan kualitas pendidikan (Riduwan, 2012). Kepala Sekolah dan guru 
yang memiliki produktivitas kerja yang tinggi cenderung disiplin dan memiliki etos kerja yang tinggi dalam bekerja, baik perencanaan, pelaksanaan dan pengawasan dalam proses kegiatan sekolah, seperti kegiatan belajar mengajar dan kelengkapan administrasi lainnya.

Kepala Sekolah dan guru yang berkinerja tinggi termotivasi dan produktif cenderung memiliki berbagai hasil karya yang dapat dilihat dan dipedomani oleh guru lain sehingga dapat menjadi motor penggerak bagi guru lain untuk menjadi motivator dan produktif dalam melaksanakan tugas-tugas pembelajaran dan pendidikan di sekolah. Jika dibandingkan dengan guru yang tidak punya kinerja, motivasi dan tidak produktif dalam menjalankan tugas-tugas di sekolah, guru yang punya kinerja, motivasi dan produktif akan lebih cepat naik pangkat dan jabatan daripada guru-guru yang tidak punya kinerja, motivasi dan tidak produktif. Akibatnya guru yang punya kinerja, motivasi dan produktif cenderung kemajuan karirnya lebih baik.

Umumnya guru-guru di Sekolah Dasar Gugus VI Kecamatan Sungaitarab Kabupaten Tanah Datar, produktivitas kerjanya sebagai guru dalam melaksanakan tugas-tugas pembelajaran dan pendidikan di sekolah dinilai masih kurang. Kenyataan ini dibuktikan dengan hasil perolehan nilai pada ujian try out untuk menghadapi ujian akhir nasional tahun ajaran 2014/2015 seperti tabel di bawah ini.

Tabel 1. Peringkat Sekolah Dalam Gugus VI Hasil Ujian Try Out Tahun Pembelajaran 2014/2015 Di Kecamatan Sungaitarab

\begin{tabular}{|c|l|c|c|c|c|c|c|c|}
\hline \multirow{2}{*}{ No } & \multirow{2}{*}{$\begin{array}{l}\text { Nama } \\
\text { Sekolah }\end{array}$} & Peringkat & \multicolumn{6}{|c|}{ Keterangan } \\
\cline { 5 - 9 } 1 & & B.Ind & IPA & IPS & MAT & PKN & Rata \\
\hline Sungaitarab & 25 dari 27 & 63,70 & 54,50 & 45,50 & 44,50 & 56,00 & 52,84 \\
\hline 2 & $\begin{array}{l}\text { SDN 07 } \\
\text { Sungaitarab }\end{array}$ & 14 dari 27 & 70,80 & 63,25 & 51,80 & 55,00 & 67,00 & 61,57 \\
\hline 3 & $\begin{array}{l}\text { SDN 14 } \\
\text { Sungaitarab }\end{array}$ & 19 dari 27 & 70,00 & 58,75 & 50,08 & 51,98 & 62,75 & 58,71 \\
\hline 4 & $\begin{array}{l}\text { SDN 17 } \\
\text { Sungaitarab }\end{array}$ & 27 dari 27 & 56,63 & 47,03 & 40,25 & 39,84 & 51,75 & 47,10 \\
\hline 5 & $\begin{array}{l}\text { SDN 26 } \\
\text { Sungaitarab }\end{array}$ & 22 dari 27 & 69,91 & 57,73 & 46,36 & 53,07 & 63,18 & 58,05 \\
\hline
\end{tabular}

Sumber: Peringkat sekolah hasil ujian try out SD TP 2014/2015 Kecamatan Sungaitarab (Data Sekolah 2014)

Perolehan rata-rata nilai dan peringkat sekolah dapat dilihat dari hasil ujian try out di atas yang menunjukkan bahwa produktivitas sekolah rendah. Diduga karena para guru tersebut kurang kinerja dan tidak termotivasi dalam melaksanakan tugasnya sebagai guru dan juga para guru tersebut tidak dapat tepat waktu untuk empat tahun pada pangkat terakhir naik pangkat kepangkat yang lebih tinggi karena angka kredit mereka tidak dapat terpenuhi dalam jangka waktu tertentu karena belum termotivasi dalam bekerja dan belum menampakkan produktivitas kerja. Dalam data yang peneliti dapatkan dari Kepala Sekolah yang ada di Gugus VI Kecamatan Sungaitarab diperoleh 26 orang guru yang telah berpangkat IVa dari 48 orang guru belum mampu untuk naik pangkat ke pangkat IVb karena produktivitas kerjanya masih rendah. 
Tabel 2. Nama Guru-Guru di Gugus VI yang Seharusnya sudah Berpangkat IVb.

\begin{tabular}{|c|l|l|}
\hline No & \multicolumn{1}{|c|}{ Nama Sekolah } & \multicolumn{1}{|c|}{ Nama Guru } \\
\hline 1 & SDN 02 Sungaitarab & Wisma \\
2 & SDN 02 Sungaitarab & Misran \\
3 & SDN 02 Sungaitarab & Benny AR Putra \\
4 & SDN 02 Sungaitarab & Yeny Widya \\
\hline 1 & SDN 07 Sungaitarab & Kamsinar \\
2 & SDN 07 Sungaitarab & Syafra Herman \\
3 & SDN 07 Sungaitarab & Yefni Elda \\
4 & SDN 07 Sungaitarab & Muslimah \\
5 & SDN 07 Sungaitarab & Yulza Elfiani \\
\hline 1 & SDN 14 Sungaitarab & Erminal \\
2 & SDN 14 Sungaitarab & Irmahayati \\
3 & SDN 14 Sungaitarab & Rusda Ulfa \\
4 & SDN 14 Sungaitarab & Irma Agusti \\
5 & SDN 14 Sungaitarab & Emiyati \\
6 & SDN 14 Sungaitarab & Zulfa Betri \\
7 & SDN 14 Sungaitarab & Syamsilas \\
8 & SDN 14 Sungaitarab & Emrita \\
9 & SDN 14 Sungaitarab & Dria Hafni Ariaswati \\
10 & SDN 14 Sungaitarab & Nurbaiti \\
\hline 1 & SDN 17 Sungaitarab & Elfi Meliyanti \\
2 & SDN 17 Sungaitarab & Ahdi Rafni \\
\hline 1 & SDN 26 Sungaitarab & Ilham \\
2 & SDN 26 Sungaitarab & Yuliarti \\
3 & SDN 26 Sungaitarab & Zulbadrianis \\
4 & SDN 26 Sungaitarab & Yasnidar \\
5 & SDN 26 Sungaitarab & \\
\hline
\end{tabular}

Sumber: Wawancara peneliti dengan Ketua Gugus VI Kecamatan Sungaitarab (Data Gugus VI Kecamatan Sungaitarab 2014)

Berdasarkan uraian deskripsi masalah di atas tersebut, terdapatlah masalah pendidikan yang sangat mendesak dan urgen sekali untuk diteliti, karena itu peneliti mengadakan penelitian tentang "Pengaruh Penilaian Kinerja dan Motivasi terhadap Produktivitas Kerja di Sekolah Dasar Gugus VI Kecamatan Sungaitarab Kabupaten Tanah Datar". Karena dengan kurangnya produktivitas kerja di SD Gugus VI Kecamatan Sungaitarab akan berdampak kurang menghasilkan lulusan SD yang bisa melanjutkan ke tingkat SLTP, dan juga akan terjadi stagnasi bagi guru-guru yang mengajar di SD Gugus VI Kecamatan
Sungaitarab, atau akan tetap berada pada pangkat yang ada sekarang.

\section{KAJIAN TEORI}

\section{Penilaian Kinerja $\left(X_{1}\right)$}

Kinerja guru dapat dilihat dari ciri guru yang baik terwujud dalam kemampuannya untuk menyusun program pembelajaran, kemampuan menguasai bahan pembelajaran, kemampuan penguasan proses pembelajaran, kemampuan melaksanakan evaluasi hasil pembelajaran, kemampuan menganalisis evaluasi hasil pembelajaran, kemampuan dalam memberikan bimbingan perbaikan pembelajaran, kemampuan dalam melaksanakan administrasi kelas dan madrasah, kemampuan menyesuaikan diri terhadap situasi dan suasana pembelajaran yang didasari oleh sikap, nilai dan kepribadian yang mantap (Usman, 2011).

Kinerja guru adalah keberhasilan seorang guru dalam melaksanakan tugasnya yang dapat diungkapkan dari kinerja yang telah dilakukannya. Dalam pengertian sederhana dapat diketahui bahwa guru adalah seorang yang mengabdi atau memberikan ilmu pengetahuan kepada peserta didiknya. Dalam arti luas dapat diungkapkan bahwa guru adalah seorang yang melaksanakan tugas di lembaga pendidikan, di mana masyarakat percaya kepadanya untuk menjalankan tugas yang dipercayakan kepadanya dalam 
rangka mencerdaskan peserta didik. Penilaian kinerja adalah menilai atau mengevaluasi kinerja karyawan, yang dimaksud di sini adalah menilai kinerja kepala sekolah dan guru yang ada di gugus VI SDN Kecamatan Sungaitarab saat ini dan atau di masa lalu relatif terhadap standar kinerjanya.

\section{Motivasi Kerja $\left(X_{2}\right)$}

Motivasi kerja guru adalah kesediaan individu atau perubahan dalam diri seseorang yang ditandai dengan dorongan yang efektif untuk mengeluarkan upaya yang tinggi untuk mencapai tujuan lembaga atau organisasi, di sini yang dimaksud dengan organisasi adalah sekolah dasar yang ada di gugus VI Kecamatan Sungaitarab. Motivasi berasal dari kata "movere" dalam bahasa latin yang artinya bergerak. Dalam arti lain adalah keinginan, harapan, kebutuhan, tujuan, sasaran, dorongan dan insentif.

Motivasi kerja guru adalah kekuatan, daya dorong yang dimiliki guru, berupa semangat, kesungguhan, rasa tanggung jawab dan kesukaan guru terhadap tugasnya. Motivasi jelas diperlukan untuk memelihara semangat dan bahkan meningkatkan semangat kerja pegawai sehingga organisasi dapat mencapai tujuan secara produktif (Engkoswara, 2011).

\section{Produktivitas Kerja (Y)}

Produktivitas kerja guru adalah yang berkaitan dengan hasil ujian yang diperoleh siswa baik secara kuantitatif maupun kualitatif dan kelancaran naik pangkat guru dalam suasana yang menyenangkan sehingga pada akhirnya diperoleh lulusan yang berkualitas sesuai dengan kebutuhan masyarakat dan perkembangan jaman. Demikian pula produktivitas di bidang pendidikan/sekolah menyangkut upaya peningkatan produksi. Sebagai sarana untuk meningkatkan produksi di bidang pendidikan adalah ketenagaan, kepandaian/keahlian, teknik pembelajaran, kurikulum, peralatan atau sarana pendidikan sebagai sistem pendidikan.

Produktivitas yang diharapkan ialah terjadinya peningkatan pengetahuan dan perilaku siswa menuju ke arah yang lebih baik maupun peningkatan kuantitas dengan dilihat dari meningkatnya siswa yang masuk. Pada dunia pendidikan lebih cenderung ke peningkatan kualitas atau mutu lulusan yang semakin tinggi. Produktivitas sekolah baik secara kuantitas dan kualitasnya dapat ditingkatkan melalui peningkatan profesionalitas kinerja guru yang mendukung baik secara langsung maupun tidak langsung.

\section{HASIL PENELITIAN DAN PEMBAHASAN}

\section{Penilaian Kinerja $\left(X_{1}\right)$}

Data variabel penilaian kinerja terhadap produktivitas kerja diperoleh dari 30 butir pernyataan. Idealnya skor variabel 
penilaian kinerja di Kelompok Kerja Guru ( KKG) Gugus VI Sungaitarab menyebar antara 124 (tertinggi) dan 74 (terendah). Selanjutnya diperoleh skor rata-rata (mean) sebesar 106.71, skor tengah (median) sebesar 109.00, skor yang banyak muncul (mode) 111 dan simpangan baku (standard deviation) 10.649. Untuk memperoleh gambaran yang jelas tentang distribusi frekuensi skor variabel penilaian kinerja terhadap produktivitas kerja di Kelompok Kerja Guru (KKG) Gugus VI Sungaitarab dapat dilihat pada tabel 10 berikut ini.

Tabel 3. Distribusi Frekuensi Skor Variabel Penilaian Kinerja ( $\left.\mathrm{X}_{1}\right)$
\begin{tabular}{|l|l|l|l|}
\hline Kelas Interval & Titik Tengah & Frekuensi & Persentase $(\%)$ \\
\hline $74-84$ & 79.5 & 3 & 6.25 \\
\hline $85-95$ & 90.5 & 0 & 0 \\
\hline $96-106$ & 101.5 & 17 & 35.42 \\
\hline $107-117$ & 112.5 & 21 & 43.75 \\
\hline $118-128$ & 123.5 & 7 & 14.58 \\
\hline Total & 48 & 100 \\
\hline
\end{tabular}

Histogram dari Distribusi Frekuensi Skor Variabel Penilaian Kinerja $\left(\mathrm{X}_{1}\right)$ dapat juga dilihat dari gambar 1 berikut ini.

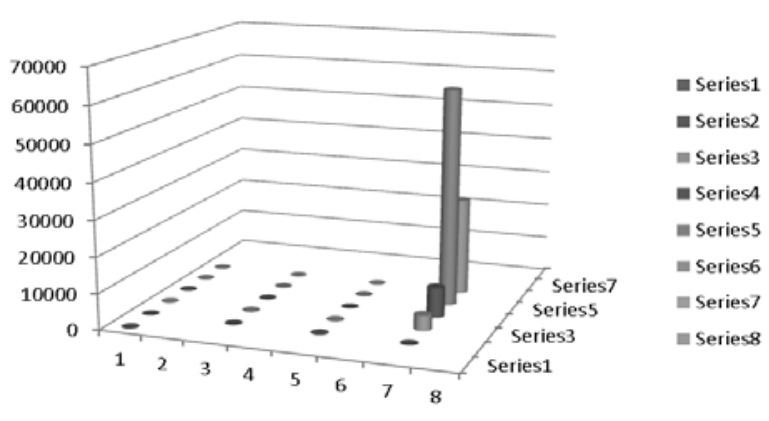

Gambar 1: Histogram Distribusi Frekuensi Skor Variabel Penilaian Kinerja

Untuk memperoleh gambaran yang jelas tentang data statistik dari variabel penilaian kinerja terhadap produktivitas kerja di Kelompok Kerja Guru (KKG) Gugus VI Sungaitarab dapat dilihat pada tabel 4 berikut.

Tabel 4. Data Statistik Variabel Penilaian Kinerja $\left(\mathrm{X}_{1}\right)$

\begin{tabular}{|l|l|}
\hline \multicolumn{1}{|c|}{ Statistik } & \multicolumn{1}{|c|}{ Penilaian Kinerja $\left(\mathrm{X}_{1}\right)$} \\
\hline $\mathrm{N}$ & 48 \\
\hline Rata-rata (mean) & 106.71 \\
\hline Skor tengah (median) & 109.00 \\
\hline Skor yang banyak muncul (mode) & 111 \\
\hline $\begin{array}{l}\text { Simpangan baku (standard } \\
\text { deviation) }\end{array}$ & 10.649 \\
\hline Skor terendah & 74 \\
\hline Skor tertinggi & 125 \\
\hline
\end{tabular}

Tingkat capaian responden pada variabel penilaian kinerja menurut rumus Qudratullah (2013) adalah:

$$
\begin{aligned}
& \text { Mean : 106,71 } \\
& \text { Skor Maksimum : } 5 \text { X 25 = 125 } \\
& \text { Tingkat Capaian Responden }=\frac{106,71}{125} \times 100 \% \\
& =\mathbf{8 5 , 3 6 \%}
\end{aligned}
$$

Untuk mengategorikan nilai pencapaian responden digunakan klasifikasi seperti Kategori Tingkat Pencapaian Responden yang dikemukakan oleh Sudjana sebagai berikut:

Tabel 5 : Tingkat Pencapaian Responden

\begin{tabular}{|l|l|}
\hline \multicolumn{1}{|c|}{ Kategori } & \multicolumn{1}{c|}{ Nilai } \\
\hline $90 \%-100 \%$ & Sangat baik \\
$80 \%-89 \%$ & Baik \\
$65 \%-79 \%$ & Cukup \\
$55 \%-64 \%$ & Kurang \\
$0 \%-54 \%$ & Tidak baik \\
\hline
\end{tabular}

Adapun tingkat pencapaian responden pada variabel penilaian kinerja guru di kelompok kerja (KKG) Gugus VI 
Sungaitarab adalah sebesar 85,36\%. Capaian ini termasuk kategori baik. Dari data ini dapat dikatakan bahwa penilaian kinerja guru di kelompok kerja (KKG) Gugus VI Sungaitarab pada umumnya berada dalam kategori baik.

\section{Motivasi Kerja $\left(X_{2}\right)$}

Data variabel motivasi kerja terhadap produktivitas kerja diperoleh dari 34 butir pernyataan. Idealnya skor variabel penilaian kinerja di Kelompok Kerja Guru (KKG) Gugus VI Sungaitarab menyebar antara 40 (tertinggi) dan 12 (terendah). Selanjutnya diperoleh skor rata-rata (mean) sebesar 26.35, skor tengah (median) sebesar 26.50, skor yang banyak muncul (mode) 22 dan simpangan baku (standard deviation) 7.268. Untuk memperoleh gambaran yang jelas tentang distribusi frekuensi skor variabel motivasi kerja terhadap produktivitas kerja di Kelompok Kerja Guru (KKG) Gugus VI Sungaitarab dapat dilihat pada tabel 6 berikut.

Tabel 6. Distribusi Frekuensi Skor Variabel Motivasi Kerja $\left(\mathrm{X}_{2}\right)$

\begin{tabular}{|l|l|l|l|}
\hline Kelas Interval & Titik Tengah & Frekuensi & Persentase (\%) \\
\hline $12-22$ & 17.5 & 16 & 33.333 \\
\hline $23-33$ & 28.5 & 25 & 52.083 \\
\hline $34-44$ & 39.5 & 7 & 14.583 \\
\hline Total & 48 & 100 \\
\hline
\end{tabular}

Histogram dari Distribusi Frekuensi Skor Variabel Motivasi Kerja $\left(\mathrm{X}_{2}\right)$ dapat juga dilihat pada gambar 2 berikut ini.

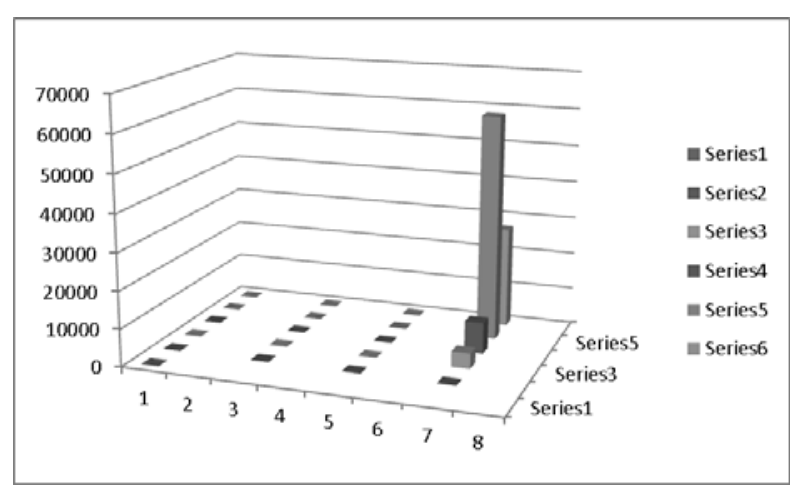

Gambar 2. Histogram Distribusi Frekuensi Skor Variabel Motivasi Kerja $\left(\mathrm{X}_{2}\right)$

Untuk memperoleh gambaran yang jelas tentang data statistik dari variabel motivasi kerja terhadap produktivitas kerja di Kelompok Kerja Guru (KKG) Gugus VI Sungaitarab dapat dilihat pada tabel 7 berikut ini.

Tabel 7 : Data Statistik Variabel Motivasi Kerja Guru (X2)

\begin{tabular}{|l|l|}
\hline \multicolumn{1}{|c|}{ Statistik } & Motivasi Kerja Guru $\left(\mathrm{X}_{2}\right)$ \\
\hline $\mathrm{N}$ & 48 \\
\hline Rata-rata (mean) & 26.35 \\
\hline Skor tengah (median) & 26.50 \\
\hline $\begin{array}{l}\text { Skor yang banyak muncul } \\
\text { (mode) }\end{array}$ & 22 \\
\hline $\begin{array}{l}\text { Simpangan baku (standard } \\
\text { deviation) }\end{array}$ & 7.268 \\
\hline Skor terendah & 12 \\
\hline Skor tertinggi & 40 \\
\hline
\end{tabular}

Tingkat capaian responden pada variabel motivasi kerja menurut rumus Muhammad Farhan Qudratullah adalah:

$$
\text { Mean :26,35 }
$$

Skor Maksimum : 5 X $10=50$

Tingkat Capaian Responden $=\frac{26,35}{50} \times 100 \%$ $=52,70 \%$

Adapun tingkat pencapaian responden pada variabel motivasi kerja guru di kelompok 
kerja (KKG) Gugus VI Sungaitarab adalah sebesar 52,70\%. Capaian ini termasuk kategori tidak baik. Dari data ini dapat dikatakan bahwa motivasi kerja guru di kelompok kerja ( KKG) Gugus VI Sungaitarab pada umumnya berada dalam kategori tidak baik.

\section{Produktivitas $(\mathrm{Y})$}

Data variabel produktivitas pendidikan diperoleh dari 32 butir pernyataan. Idealnya skor variabel produktivitas kerja di Kelompok Kerja Guru (KKG) Gugus VI Sungaitarab menyebar antara 126 (tertinggi) dan 83 (terendah). Selanjutnya diperoleh skor rata-rata (mean) sebesar 111,02, skor tengah (median) sebesar 111,50, skor yang banyak muncul (mode) 112 dan simpangan baku (standard deviation) 9.033. Untuk memperoleh gambaran yang jelas tentang distribusi frekuensi skor variabel produktivitas kerja di Kelompok Kerja Guru (KKG) Gugus VI Sungaitarab dapat dilihat pada tabel 8 berikut ini.

Tabel 8: Distribusi Frekuensi Skor Variabel Produktivitas Pendidikan (Y)

\begin{tabular}{|l|l|l|l|}
\hline Kelas Interval & Titik Tengah & Frekuensi & Persentase (\%) \\
\hline $83-93$ & 88.5 & 2 & 4.166 \\
\hline $94-104$ & 99.5 & 4 & 8.333 \\
\hline $105-115$ & 110.5 & 29 & 60.416 \\
\hline $116-126$ & 121.5 & 13 & 27.083 \\
\hline Total & 48 & 100 \\
\hline
\end{tabular}

Histogram dari Distribusi Frekuensi Skor Variabel Produktivitas Pendidikan (Y) dapat juga dilihat dari gambar 3 berikut ini.

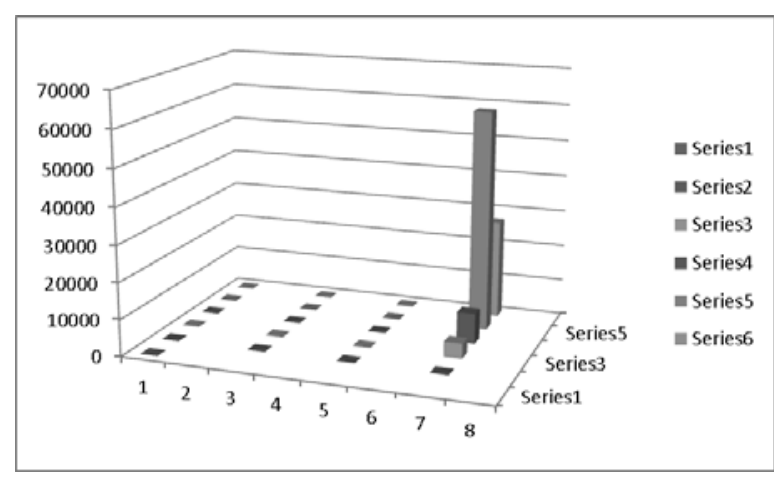

Gambar 3. Histogram Distribusi Frekuensi Skor Variabel Produktivitas $(\mathrm{Y})$

Untuk memperoleh gambaran yang jelas tentang data statistik dari variabel produktivitas kerja di Kelompok Kerja Guru (KKG) Gugus VI Sungaitarab dapat dilihat pada tabel 9 berikut ini.

Tabel 9. Data Statistik Variabel Produktivitas Pendidikan (Y)

\begin{tabular}{|l|l|}
\hline \multicolumn{1}{|c|}{ Statistik } & Produktivitas Pendidikan (Y) \\
\hline $\mathrm{N}$ & 48 \\
\hline Rata-rata (mean) & 111.02 \\
\hline Skor tengah (median) & 111.50 \\
\hline $\begin{array}{l}\text { Skor yang banyak muncul } \\
\text { (mode) }\end{array}$ & 112 \\
\hline $\begin{array}{l}\text { Simpangan baku (standard } \\
\text { deviation) }\end{array}$ & 9.033 \\
\hline Skor terendah & 83 \\
\hline Skor tertinggi & 126 \\
\hline
\end{tabular}

Tingkat capaian responden pada variabel motivasi kerja menurut rumus Qudratullah (2013) adalah:

Mean $\quad: 111,02$

Skor Maksimum : 5 X $27=135$

Tingkat Capaian Responden $=\frac{111,02}{135} \times 100 \%$ $=82,23 \%$

Adapun tingkat pencapaian responden pada variabel produktivitas kerja guru 
di kelompok kerja (KKG) Gugus VI Sungaitarab adalah sebesar $82,23 \%$. Capaian ini termasuk kategori baik. Dari data ini dapat dikatakan bahwa produktivitas kerja guru di kelompok kerja (KKG) Gugus VI Sungaitarab pada umumnya berada dalam kategori baik.

\section{KESIMPULAN}

Berdasarkan data dan hasil analisis yang telah dipaparkan dapat ditarik kesimpulan sebagai berikut.

1. Hasil penelitian menunjukkan bahwa Penilaian Kinerja berpengaruh terhadap produktivitas kerja sebesar 85,36\%, varian yang terjadi pada penilaian kinerja guru mempengaruhi produktivitas kerja. Produktivitas kerja dapat sempurna atau $100 \%$ bila penilaian kinerja guru sering dilakukan oleh pengawas pendidikan pada tingkat kecamatan ataupun tingkat kabupaten.

2. Hasil penilaian menunjukkan bahwa Motivasi Kerja Guru berpengaruh terhadap produktivitas kerja sebesar 52, $70 \%$, varian yang terjadi pada motivasi kerja mempengaruhi produktivitas kerja. Produktivitas kerja guru dapat ditingkatkan apabila guru termotivasi untuk bekerja. Pada guru di KKG Gugus VI Sungaitarab motivasi guru dikategori tidak baik, ini dikarenakan guru sudah tidak termotivasi lagi bekerja sebab tidak bisa untuk naik pangkat ke pangkat yang lebih tinggi.

3. Hasil penelitian menunjukkan bahwa Penilaian Kinerja dan Motivasi Kerja Guru berpengaruh terhadap produktivitas kerja sebesar $85,36 \%$ dan 52,70\%. Variansi yang terjadi pada penilaian kinerja dan motivasi kerja secara bersama mempengaruhi produktivitas kerja. Semakin sering penilaian kinerja dilakukan dan semakin tinggi motivasi guru untuk bekerja maka produktivitas pembelajaran dan hasil produktivitas pendidikan di sekolah akan tercapai.

Dengan melihat hasil penelitian ini, maka guru-guru di KKG Gugus VI Kecamatan Sungaitarab harus berusaha meningkatkan Penilaian Kinerja dan Motivasi Kerja agar Produktivitas Pendidikan bisa meningkat maka mutu sekolah yang ada di Gugus VI Kecamatan Sungaitarab pun dapat meningkat.

\section{KEPUSTAKAAN ACUAN}

Engkoswara. (2011). Administrasi Pendidikan. Bandung: Alfabeta.

Qudratullah, Muhammad Farhan. (2013). Analisis Regresi Terapan dan Aplikasi dengan SPSS, Yogyakarta: Penerbit Andi. 
Riduwan. (2012). Metode \& Teknik Usman, Husaini. (2011). Manajemen Teori Menyusun Proposal Penelitian. Bandung: $\quad$ Praktek dan Riset Pendidikan. Jakarta: Alfabeta. Bumi Aksara. 